\title{
Full Soft-Switching Bidirectional Isolated Current-Fed Dual Inductor Push-Pull DC-DC Converter for Battery Energy Storage Applications
}

\author{
Roman Kosenko ${ }^{1,2}$, Janis Zakis ${ }^{3}$, Andrei Blinov ${ }^{1}$, Andrii Chub ${ }^{1}$, Oleksandr Veligorskyi ${ }^{2}$ \\ ${ }^{1}$ Department of Electrical Engineering \\ Tallinn University of Technology \\ Tallinn, Estonia \\ ${ }^{3}$ Institute of Industrial Electronics and Electrical Engineering \\ Riga Technical University \\ Riga, Latvia
}

${ }^{2}$ Department of Biomedical Radioelectronic Apparatus and Systems

Chernihiv National University of Technology

Chernihiv, Ukraine

\begin{abstract}
This paper presents a novel bidirectional currentfed dual inductor push-pull DC-DC converter with galvanic isolation. The converter features active voltage doubler rectifier, which is controlled by the switching sequence synchronous to that of the input-side switches. The control algorithm proposed enables full-soft-switching of all switches in a wide range of the input voltage and power without requirement of snubbers or resonant switching to be employed. Operation principle for the energy transfer in the both directions is described. Experimental results as well as basic design guidelines are presented.
\end{abstract}

Keywords-current-fed dc-dc converter; bidirectional converter; full soft-switching; ZVS; ZCS; dual inductor, push-pull converter; switching control method, naturally clamped, battery, energy storage

\section{INTRODUCTION}

In recent years green energy policy of European Union fosters implementation of distributed and alternative power generation sources [1]. For better renewable energy utilization in residential applications it is feasible to implement systems with photovoltaics (PV) or wind generators together with battery energy storages (BES) [2]-[5]. Battery energy storage systems (BESS) could be utilized as energy buffer to react on short, high electric energy demand spikes or reduce the impact of renewable power generation unpredictability [6]. Moreover, BESS can be used for power quality issue solving in the point of common coupling with the distribution grid.

The power of residential BESSs varies in the range from hundreds of Watts up to $10 \mathrm{~kW}$ for the most critical appliances. Multiplicity of chemical composition of batteries also varies depending on applications. For example, the lithium iron phosphate $\left(\mathrm{LiFePO}_{4}\right)$ type batteries are characterized by high safety, long lifetime, high number of recharging cycles and acceptable cost [7]-[9].

For interconnection of BESS with residential appliances the DC-AC converter is usually required. The adjustment of intermediate DC-link voltage of interface converter has been done by various voltage source DC-DC converters [10],[11].
Dual active bridge (DAB) is a reliable and widely adopted solution, which provided soft switching and high efficiency [12]. In recent years, current-fed (CF) converters that inherit mentioned advantages are introduced as well. Those include soft switching due to active clamping [13],[14], resonant switching [15], active snubber [16], utilization of parasitic resonance [17] etc. In addition, CF converters enable low input current ripple and are referred as reliable solutions for battery and fuel cell interfacing [10],[11].

Comparison between two CF push-pull DC-DC converters (single inductor and dual inductor) types was presented in [18]. The benefits of dual inductor converter are: reduced voltage across the main switches, lower current stress on inductors, reduced RMS current ripple in the output capacitor, smaller size of the transformer and each of the input inductors.

Several dual inductor push-pull converter topologies have been evaluated and proposed in recent years, however they all have significant drawbacks. The converter proposed in [19] inherits active clamping circuit to mitigate voltage overshoots, but has limited range of soft switching and complicated secondary circuit. The advantage of circuit in [20] is simple output part, but the drawback is the variable frequency control utilized. In [21] the utilization of switches is only partial since they operate only for a short time, while parallel diode is conducting during the rest of the switching period. Topology described in [22] also has insufficient utilization of transistors and exhibits hard switching of the output transistors.

Implementation of active control strategy of the secondary side switches brings new challenges and benefits for isolated CF converters [23]-[29]. Among the advantages for battery storage applications is the possibility of bidirectional operation. This paper proposes $\mathrm{CF}$ dual inductor push-pull DC-DC converter with switching control method, which does not require complicated calculations that depend on operation points and results in robust soft switching behavour. Despite higher number of active switches, which increase conduction losses the high overall efficiency due to soft-switching can be achieved. 


\section{GENERAL DESCRIPTION}

The proposed converter topology is shown in Fig. 1. It consists of the CF dual inductor push-pull switching stage in the input low-voltage side and the active voltage doubler rectifier in the output voltage-fed (VF) side. The converter features soft-switching operation of all semiconductor components in a wide range of the input voltage and power, while providing natural clamping of the input $\mathrm{CF}$ side switches. Galvanic isolation allows interfacing of low-voltage batteries to the DC bus with much higher voltage rating, or to the utility grid. Converter maintains soft-switching properties in bidirectional operating mode and provides continuous current at the battery terminals that are connected to the CF terminal of the converter. The main drawback of this converter is relatively high number of active switches (even though it was reduced when compared to the full-bridge counterpart [29]), which results in additional driving and conduction losses. Output voltage regulation is achieved by controlling the duration of energy return intervals (when part of the energy is transferred from the output to the input terminal). These intervals are usually minimized due to additional losses. The parasitic output capacitance of the switches $\mathrm{S}_{3}, \mathrm{~S}_{4}$ can be used as snubber capacitors $\mathrm{C} 1-\mathrm{C} 2$.

Full soft-switching dual inductor push-pull (FSS-DIPP) topology has the following advantages compared to the full soft switching isolated full-bridge boost converter (FSSIFBBC) proposed earlier [29]:

- higher gain;

- number of switches in the high current CF terminal is reduced by half, which results in lower conduction losses;

- duty-cycle of 4Q switches is always greater than 0.5 , therefore it never operates in discontinuous conduction mode (DCM) ;

- zero current ripple at the $\mathrm{CF}$ side in normal mode $\left(\mathrm{D}_{\mathrm{REV}}=0\right)$, even if $\mathrm{L}_{\mathrm{A}}$ and $\mathrm{L}_{\mathrm{B}}$ operate near the BCM.

In the forward operation mode the bottom transistors of the current-fed four-quadrant (4Q) switches (S1.2 and S2.2) operate as diodes during the transient intervals. In reverse operation mode the converter topology can be regarded as the VF isolated half-bridge with current doubler rectifier at the secondary side. In this mode top transistors of 4Q switches operate as diodes during transition intervals to provide softswitching operation. One of the benefits of the topology proposed is that it is possible to get both positive and negative

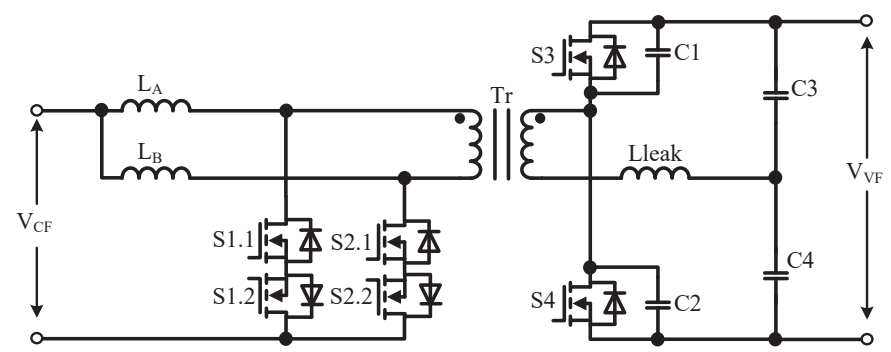

Fig. 1. Full-soft-swithicng CF push-pull converter proposed.

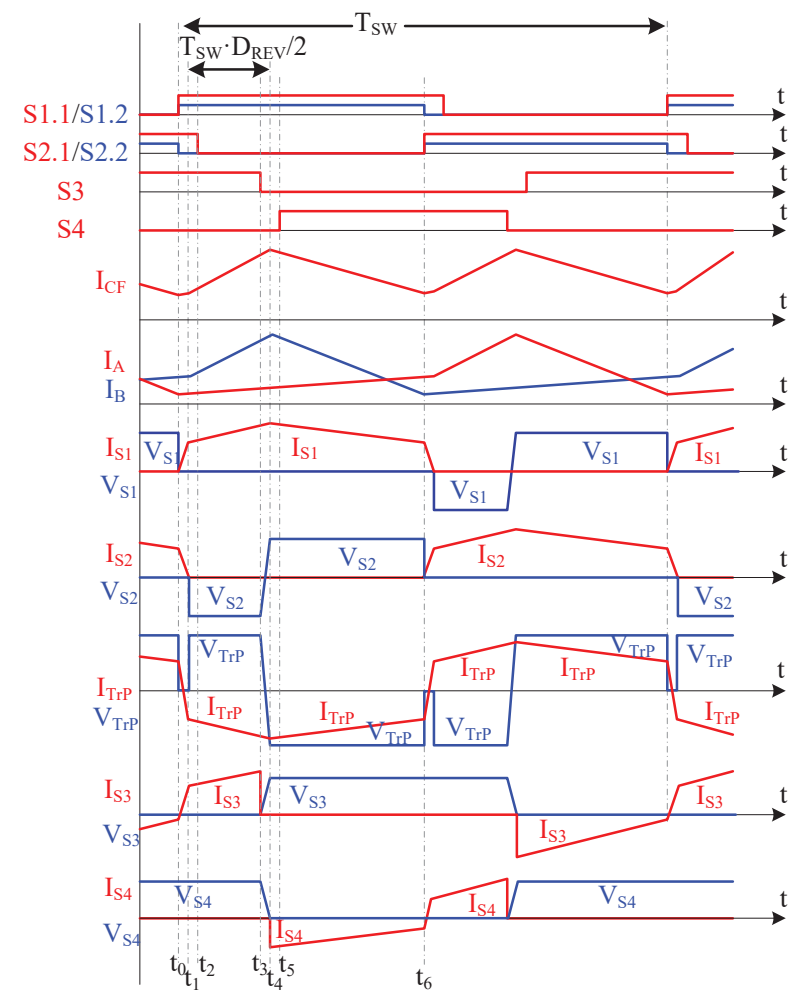

Fig. 2. Generalized waveforms for the forward operation mode.

polarity of $\mathrm{V}_{\mathrm{CF}}$. In this paper the operation only for positive polarity is described as it is relevant for battery applications. To get negative polarity it is enough to swap control signals of the 4Q switches $\mathrm{S} 1$ and $\mathrm{S} 2$.

\section{FORWARD OPERATION MODE OF THE CONVERTER}

This section describes the forward operation mode, i.e. then the power is transferred from terminals $V_{C F}$ to $V_{V F}$. Generalized current and voltage waveforms for this operation mode are shown in Fig. 2. The converter operation can be described by six time intervals within half of the switching period $\mathrm{T}_{\mathrm{SW}}$.

Interval $1\left(t_{0}<t<t_{1}\right.$, Fig. 3a). At the instant $t_{0}$ switch $S 2.2$ is turned off. The body diode (BD) of S2.2 conducts the current. 4Q switch S1 is turned on with ZVS, assisted by the transformer leakage inductance. The inductor $\mathrm{L}_{\mathrm{A}}$ is accumulating energy from the input source through the $4 \mathrm{Q}$ switch $\mathrm{S} 1$. The inductors $\mathrm{L}_{\mathrm{A}}$ and $\mathrm{L}_{\mathrm{B}}$ are accumulating energy. Switch S3 is still turned on and thus forces the transformer primary winding current redistribution between the 4Q switches, from S2 to S1.

Interval $2\left(\mathrm{t}_{1}<\mathrm{t}<\mathrm{t}_{2}\right.$, Fig. 3b). At the instant $\mathrm{t}_{1}$ current through S2 drops to zero causing BD of S2.2 to turn off naturally. Starting from this instant the converter is in reverse energy transfer mode (form VF to CF terminal). The inductor $\mathrm{L}_{\mathrm{A}}$ is accumulating energy from $\mathrm{CF}$ terminal, while $\mathrm{L}_{B}$ is accumulating energy from the both $\mathrm{CF}$ and VF terminals. The switch S2.1 is not conducting current and can be turned off with ZCS. The duration of this interval should be long enough to ensure that current has sufficient time to redistribute in the whole converter operation range. 


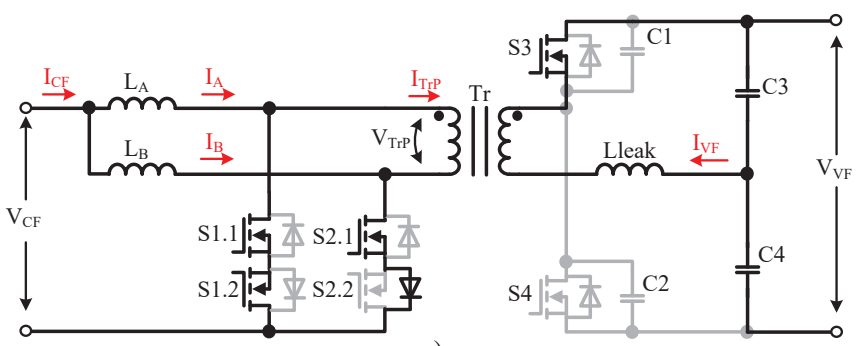

a)

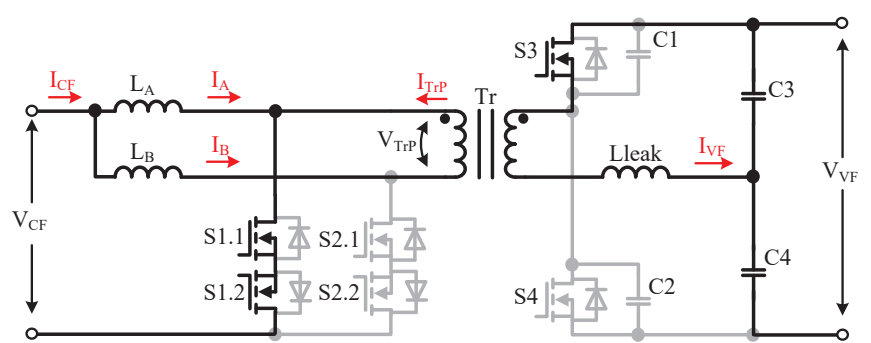

c)

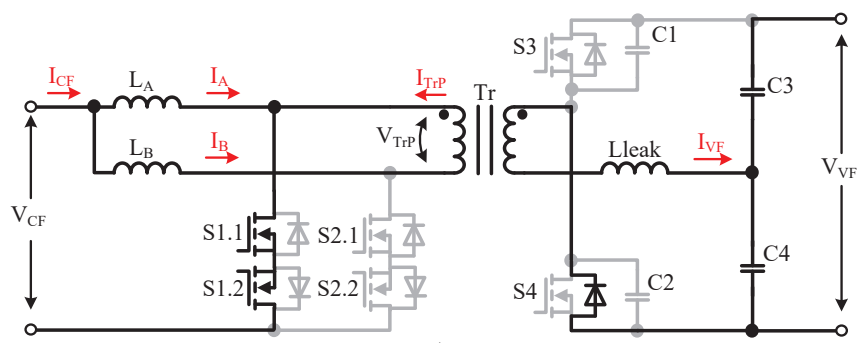

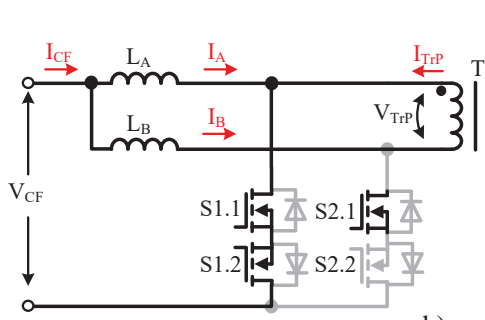

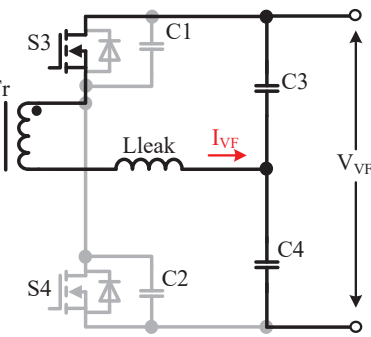

b)

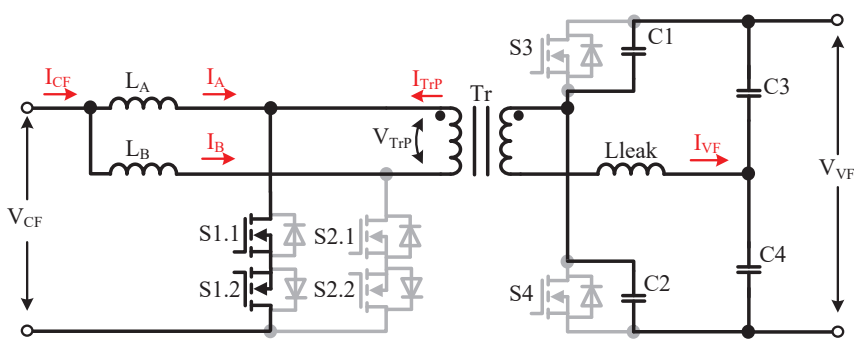

d)

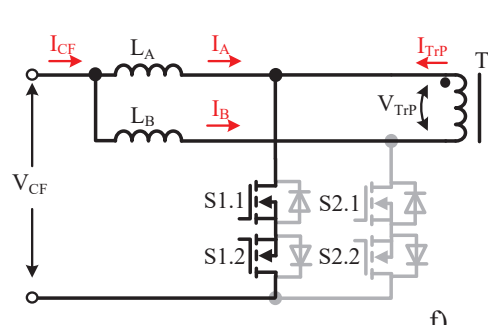

f)

Fig. 3. Equivalent circuits for the forward operation mode.

Interval $3\left(t_{2}<t<t_{3}\right.$, Fig. 3c). Switch $\mathrm{S} 2.1$ is turned off with ZCS. Processes in this interval are similar to the previous one and its duration defines the converter gain factor.

Interval $4\left(\mathrm{t}_{3}<\mathrm{t}<\mathrm{t}_{4}\right.$, Fig. 3d). At the instant $\mathrm{t}_{3}$ the switch S3 is turned off with snubber-assisted soft-switching. This results in recharging of snubber capacitors $\mathrm{C} 1$ from zero to $\mathrm{V}_{\mathrm{VF}}$ and $\mathrm{C} 2$ from $\mathrm{V}_{\mathrm{VF}}$ to zero. The voltage polarity of the transformer windings is changed.

Interval $5\left(t_{4}<t<t_{5}\right.$, Fig. 3e). At the instant $t_{4} B D$ of the switch S4 starts conducting the transformer current and the power delivery mode starts. Energy stored in the inductor $L_{B}$ is transferred to the VF terminal through the 4Q switch S1 and $\mathrm{BD}$ of the switch S4. This interval is required to ensure that the snubber capacitors will have enough time to recharge in whole converter operation range and should be optimized to minimize BD conduction losses.

Interval $6\left(t_{5}<t<t_{6}\right.$, Fig. 3f). The switch $\mathrm{S} 4$ is turned on with ZVS at the instant $t_{5}$. Energy is transferred from CF to VF terminal through 4Q switch S1 and switch S4. Afterwards the similar processes repeat for other half-period.

DC voltage gain of the CF part can be expressed as follows:

$$
F_{F R W}=\frac{V_{V F}}{2 n V_{C F}}=\frac{1}{1-2 \cdot\left(D_{R E V}+t_{0-1}+t_{4-5}+t_{5-6}\right)},
$$

where $\mathrm{n}$ is the transformer turns ratio.
The duration of snubber recharge (interval 5) and current redistribution (interval 1) intervals is generally negligibly small as compared to energy circulation (interval 3) and energy accumulation and transfer (interval 6) intervals. Hence, simplified equation for the normalized DC voltage gain of the converter in the forward operation mode (Fig. 4) can be expressed as:

$$
F_{F R W}=\frac{V_{V F}}{2 n V_{C F}}=\frac{2}{1-4 \cdot D_{R E V}},
$$

\section{REVERSE Operation MOdE OF THE CONVERTER}

This section describes the reverse operation mode, when the power is transferred from VF to CF terminals (Fig. 5). This operation mode can used for battery charging in BESS.

Interval $1\left(t_{0}<t<t_{1}\right.$, Fig. 6a). At the instant $t_{0}$ the switch S2.1 is turned off. The body diode (BD) of S2.1 conducts the current. The 4Q switch S1 is turned on with ZVS, assisted by the transformer leakage inductance. The transformer current $\mathrm{I}_{\mathrm{TRp}}$ is redistributing between the $4 \mathrm{Q}$ switches, from $\mathrm{S} 1$ to $\mathrm{S} 2$, and changes its sign. Transformer primary voltage drops to zero. The inductors $L_{A}$ and $L_{B}$ feed the load.

Interval $2\left(t_{1}<t<t_{2}\right.$, Fig. 6b). At the instant $t_{1}$ current through the 4Q switch S2 drops to zero causing the BD of S2.1 to turn off. Power delivery mode starts. From this instant the switch S2.2 can be switched off with ZCS. Energy is 


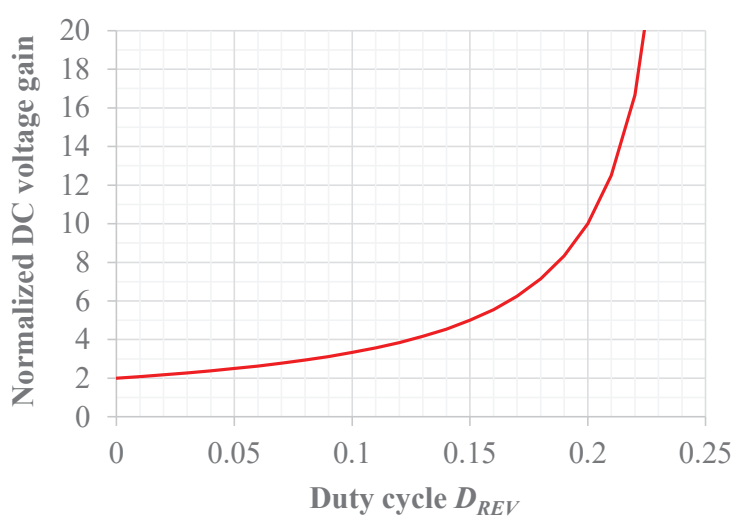

Fig. 4. Normalized DC voltage gain in the forward operation mode.

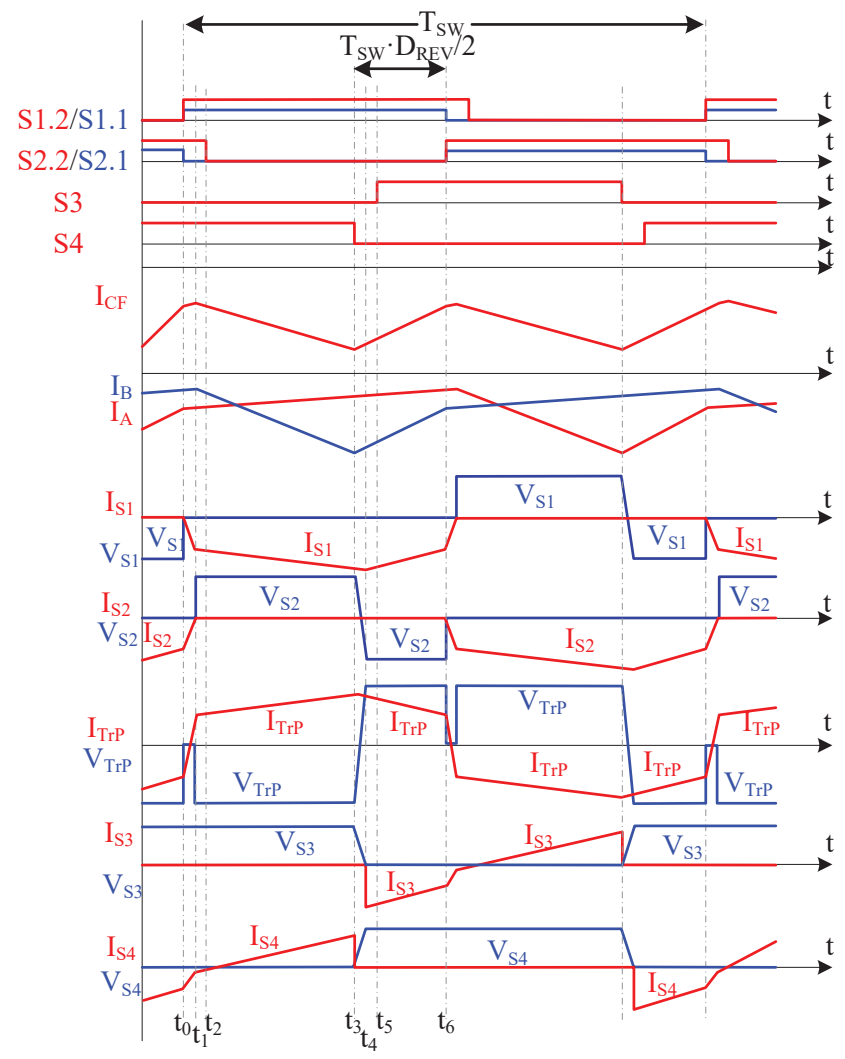

Fig. 5. Generalized waveforms for the reverse operation mode.

transferred through the switch S4 and the 4Q switch S1 from $\mathrm{VF}$ to $\mathrm{CF}$ terminal. This interval is needed to ensure that the current through S2 drops to zero.

Interval $2\left(t_{1}<t<t_{2}\right.$, Fig. 6b). At the instant $t_{1}$ current through the 4Q switch S2 drops to zero causing the BD of S2.1 to turn off. Power delivery mode starts. From this instant the switch S2.2 can be switched off with ZCS. Energy is transferred through the switch S4 and the 4Q switch S1 from VF to CF terminal. This interval is needed to ensure that the current through $\mathrm{S} 2$ drops to zero.

Interval $3\left(t_{2}<t<t_{3}\right.$, Fig. 6c). Switch $S 2.2$ is turned off with ZCS at the instant $t_{2}$. Power delivery mode continues.
Interval $4\left(t_{3}<t<t_{4}\right.$, Fig. $\left.6 d\right)$. The switch $\mathrm{S} 4$ turns off with snubber-assisted soft-switching at the instant $t_{3}$. This results in recharging of the snubber capacitors: $\mathrm{C} 2$ from zero to $\mathrm{V}_{\mathrm{VF}}$ and $\mathrm{C} 1$ from $\mathrm{V}_{\mathrm{VF}}$ to zero. Reverse energy transfer mode is started. The load current is maintained by $\mathrm{L}_{\mathrm{A}}$ through $4 \mathrm{Q}$ switch $\mathrm{S} 1$. Energy accumulated in the inductor $\mathrm{L}_{\mathrm{B}}$ is transferred from $\mathrm{CF}$ to VF terminal.

Interval $5\left(t_{4}<t<t_{5}\right.$, Fig. 6e). At the instant $t_{4}$ the transformer voltage polarity is changed causing BD of S3 to turn on. Power delivery mode starts, energy is transferred from VF to CF terminal. In this mode, the load current is the sum of the currents $\mathrm{I}_{\mathrm{A}}$ and $\mathrm{I}_{\mathrm{B}}$. This interval is needed to ensure that snubber capacitors are recharged and should be optimized to minimize the BD conduction losses.

Interval $6\left(t_{5}<t<t_{6}\right.$, Fig. 6f). At the instant $t_{5} \mathrm{~S} 3$ turns on with ZVS. Reverse energy transfer mode continues with reduced conduction losses.

Similar to the forward operating mode, the equation for the normalized DC voltage gain of the converter operating in the reverse operation mode (Fig. 7) can be simplified to:

$$
F_{R E V}=\frac{2 n V_{C F}}{V_{V F}}=0.5-2 \cdot D_{R E V} .
$$

\section{EXPERIMENTAL RESULTS}

As a test profile for the experimental verification $\mathrm{LiFePO}_{4}$ charge/discharge curve was selected. Normal operation range of single $\mathrm{LiFePO}_{4}$ cell varies from $2.5 \mathrm{~V}$ at deep discharge up to $3.65 \mathrm{~V}$ at full charge which gives operation voltage range of $10 \ldots 15 \mathrm{~V}$ for a standard 4-cell battery.

The main operation parameters of the prototype are presented in Table I. Table II presents equations to compare major parameters of DiPP and FSS-IFBB [29]. $D_{\text {Smax }}$ and $D_{\text {REVmax }}$ were selected so that at lowest operation voltage $\mathrm{CF}$ stage will have gain factor high enough to obtain nominal output voltage at the VF terminal. Transformer turns ratio is selected so that $D_{\mathrm{REV}}$ should be close to zero at the maximal input voltage of the $\mathrm{CF}$ side. As can be seen from equations, the input current is equally distributed among the CF terminal inductors, but to maintain the same level of input current ripple in proposed topology, two inductors with higher total inductance than in case of FSS-IFBB are required. Table III describes the main parameters of semiconductor devices utilized in this prototype.

In the compared topologies, magnetic elements operate in different conditions and to evaluate their weight-size parameters, stored energy equations are presented in Table II. As seen from equations, energy stored in the magnetic element of proposed topology is 1.6 times lower than in case of FSSIFBB. In other words. size and cost of the inductors in the proposed converter could be lower than that in the FSS-IFBB due to higher value of inductance with lower current rating.

Experimental results are presented in Table IV. The theoretical voltage gain differs from experimental. It can be explained by the use of simplified theoretical equation that does not take into account durations of auxiliary and transient 


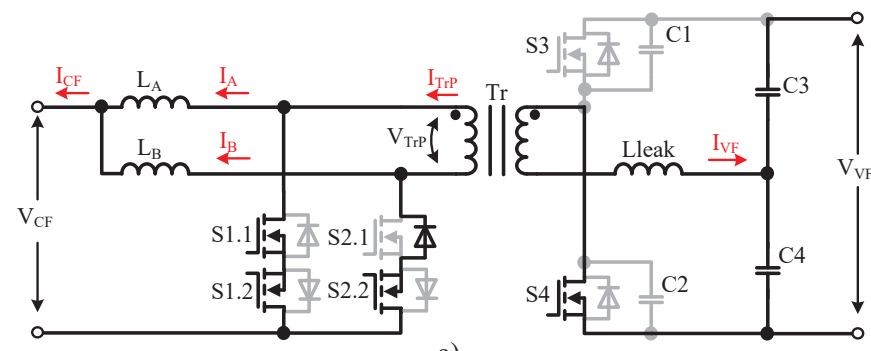

a)

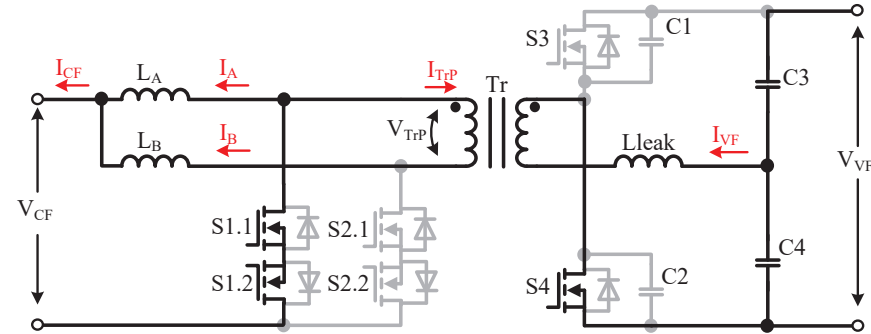

c)

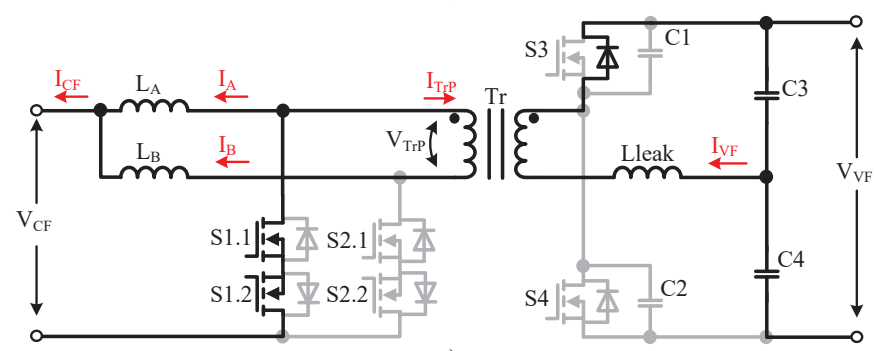

e)

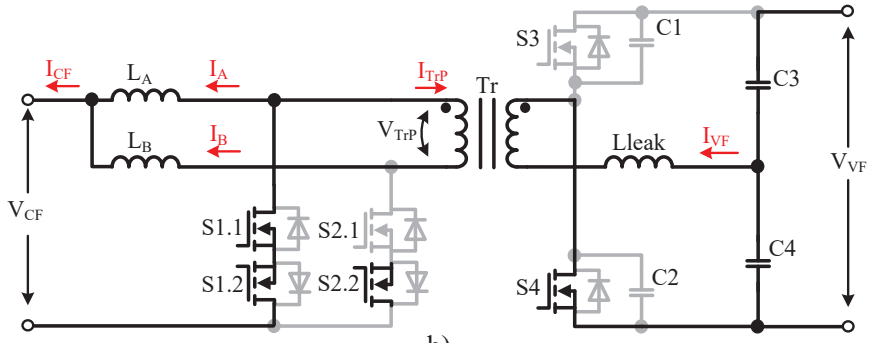

b)

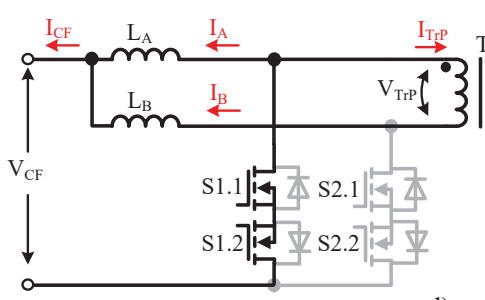

d)

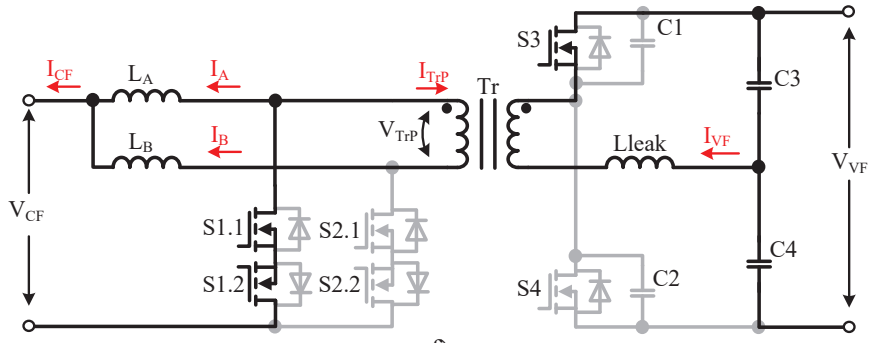

f)

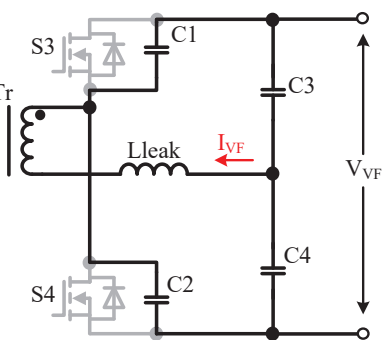

Fig. 6. Equivalent circuits for the reverse operation mode.

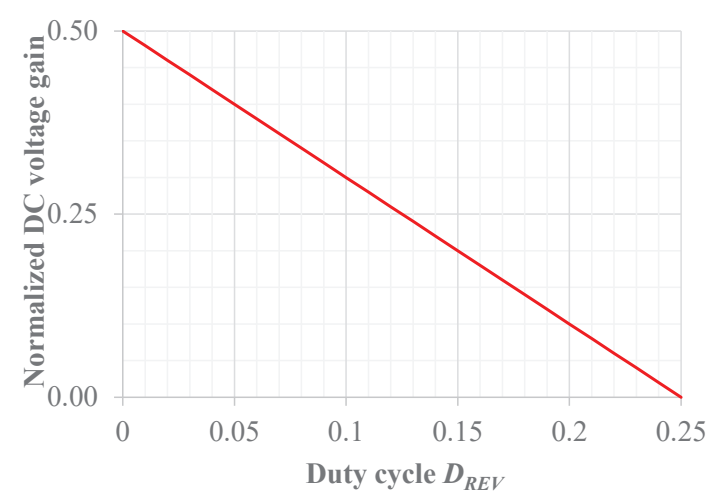

Fig. 7. Normalized DC voltage gain in the reverse operation mode.

time intervals. These intervals were chosen to ensure robust soft-switching in the whole operational range. This means that for different operational points these intervals are not welloptimized. For example, at minimal boost $(15 \mathrm{~V})$ maximum current through CF switches is 1.5 smaller than in the point of maximal boost $(10 \mathrm{~V})$. This means that current-redistribution interval $\left(t_{0}-t_{1}\right.$ in Fig. 2$)$ will be smaller and the reverse energy transfer will start earlier (instant $t_{1}$ ). It is easy to see that semiconductor losses are mainly determined by conduction losses (Fig. 8) that increase proportional to the squared input current. Experiment showed that the reverse operation mode provides the same efficiency values as in the forward mode for the corresponding operating points due to deep similarity between operating conditions of the semiconductors in the both modes. In addition, the reverse operating mode maintains the full soft-switching operation.

Experimental current and voltage waveforms of converter for the operation point with $\mathrm{V}_{\mathrm{IN}}=12 \mathrm{~V}, \mathrm{P}=100 \mathrm{~W}$ are presented in Figs 9-13 for the forward mode. As shown, they correspond to theoretically predicted waveforms and confirm soft-switching operation of all semiconductor elements.

TABLE I. OPERATING PARAMETERS OF THE EXPERIMENTAL CONVERTER

\begin{tabular}{|l|c|c|}
\hline \multicolumn{1}{|c|}{ Parameter } & Symbol & Value \\
\hline Rated power, $\mathrm{W}$ & $P$ & 100 \\
\hline Input voltage, $\mathrm{V}$ & $V_{C F}$ & $10-15$ \\
\hline Output voltage, $\mathrm{V}$ & $V_{V F}$ & 400 \\
\hline Switching frequency, $\mathrm{kHz}$ & $f_{S W}$ & 100 \\
\hline Transformer turns ratio (Np/Ns) & $n$ & 6 \\
\hline Transformer magnetizing inductance, $\mathrm{mH}$ & $L_{T X}$ & 3.4 \\
\hline Transformer secondary leakage ind., $\mathrm{uH}$ & $L_{T X}$ leak & 8 \\
\hline Inductance of input inductors, $\mathrm{uH}$ & $L_{A}, L_{B}$ & 44 \\
\hline Capacitance of filter capacitor, $\mathrm{uF}$ & $C_{3}, C_{4}$ & 2.2 \\
\hline Capacitance of snubber capacitor, $\mathrm{pF}$ & $C_{1}-C_{6}$ & 265 \\
\hline
\end{tabular}


TABLE II. COMPARISON OF THE DESIGN PARAMEETERS

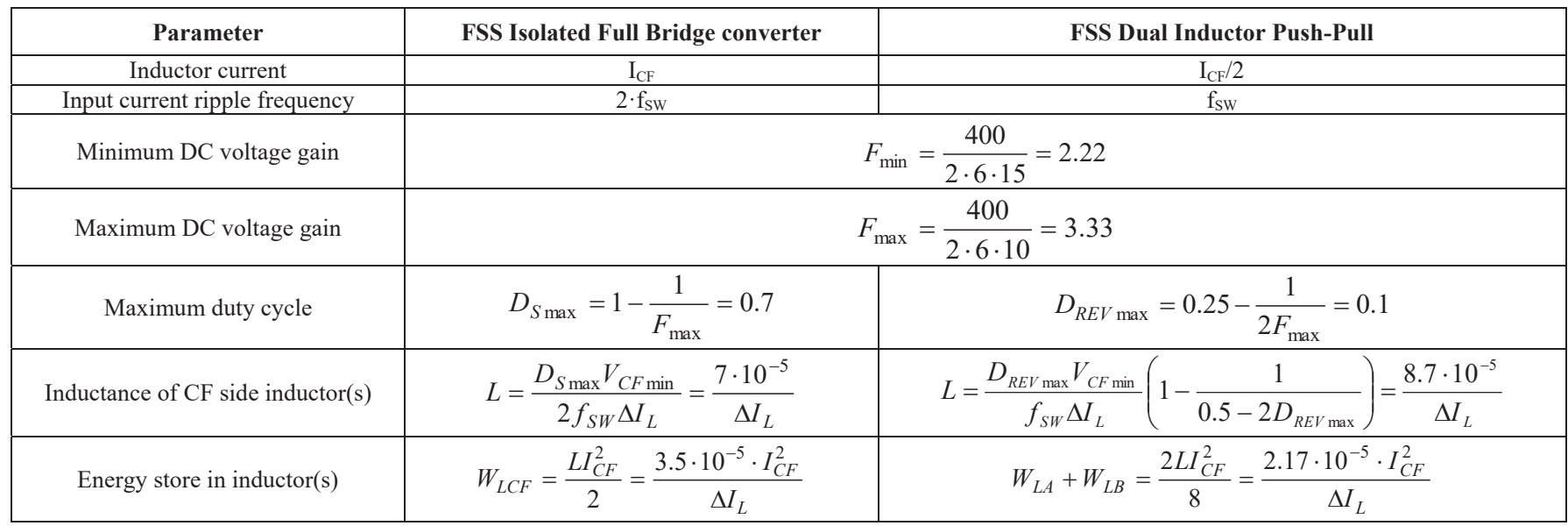

TABLE III. TyPES AND PARAMETERS OF SEMICONDUCTOR DEVICES USED

\begin{tabular}{|c|c|c|}
\hline Component & Type & Specifications \\
\hline CF MOSFETs & $\begin{array}{c}\text { Infineon } \\
\text { BSC035N10NS5 }\end{array}$ & $\begin{array}{c}\mathrm{V}_{\mathrm{DS}}=100 \mathrm{~V} ; \mathrm{R}_{\mathrm{DS}(\mathrm{on})}=3.5 \mathrm{~m} \Omega \\
\mathrm{I}_{\mathrm{D}}=100 \mathrm{~A}, \mathrm{t}_{\mathrm{rr}}=62 \mathrm{~ns}, \mathrm{C}_{\mathrm{OSS}}=770 \mathrm{pF}\end{array}$ \\
\hline VF MOSFETs & $\begin{array}{c}\text { ROHM } \\
\text { SCT2120AF }\end{array}$ & $\begin{array}{c}\mathrm{V}_{\mathrm{DS}}=650 \mathrm{~V} ; \mathrm{R}_{\mathrm{DS}(\mathrm{on})}=120 \mathrm{~m} \Omega \\
\mathrm{I}_{\mathrm{D}}=29 \mathrm{~A}, \mathrm{t}_{\mathrm{rr}}=33 \mathrm{~ns}, \mathrm{C}_{\mathrm{OSS}}=90 \mathrm{pF}\end{array}$ \\
\hline
\end{tabular}

TABLE IV. EXPERIMENTAL RESULTS

\begin{tabular}{|c|c|c|c|c|c|}
\hline $\mathbf{V}_{\mathbf{C F}}, \mathbf{V}$ & $\mathbf{D}_{\mathbf{R E V}}$ & $\begin{array}{c}\text { Theoretical } \\
\text { gain }\end{array}$ & $\begin{array}{c}\text { Experim. } \\
\text { gain }\end{array}$ & Losses, W & $\mathbf{\eta}, \mathbf{\%}$ \\
\hline 10 & 0.101 & 3.36 & 3.33 & 5.940 & 94.06 \\
\hline 11 & 0.084 & 3.02 & 3.03 & 5.040 & 94.96 \\
\hline 12 & 0.064 & 2.69 & 2.78 & 4.110 & 95.89 \\
\hline 13 & 0.046 & 2.46 & 2.56 & 3.580 & 96.42 \\
\hline 14 & 0.032 & 2.29 & 2.38 & 3.190 & 96.81 \\
\hline 15 & 0.006 & 2.05 & 2.22 & 2.760 & 97.24 \\
\hline
\end{tabular}

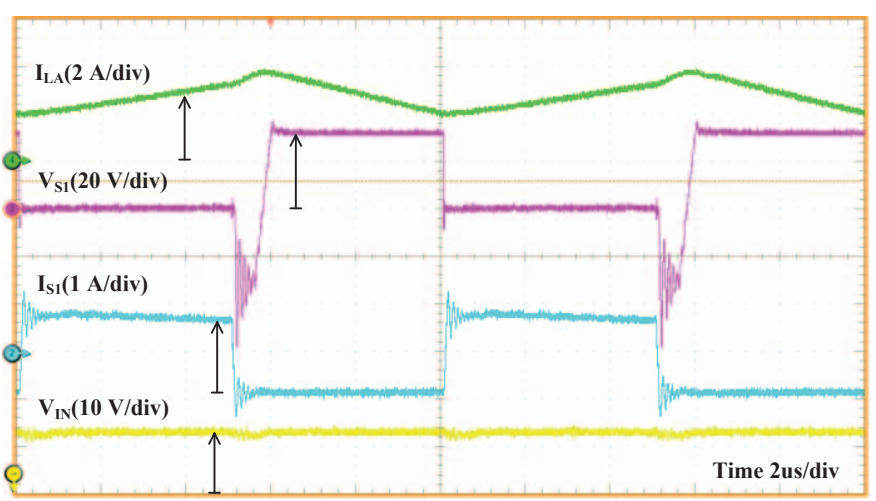

Fig. 9. Current through the inductor $\mathrm{L}_{\mathrm{A}}\left(\mathrm{I}_{\mathrm{A}}\right)$, voltage and current across switch $\mathrm{S} 1$ and converter input voltage $\left(\mathrm{V}_{\mathrm{IN})}\right.$.

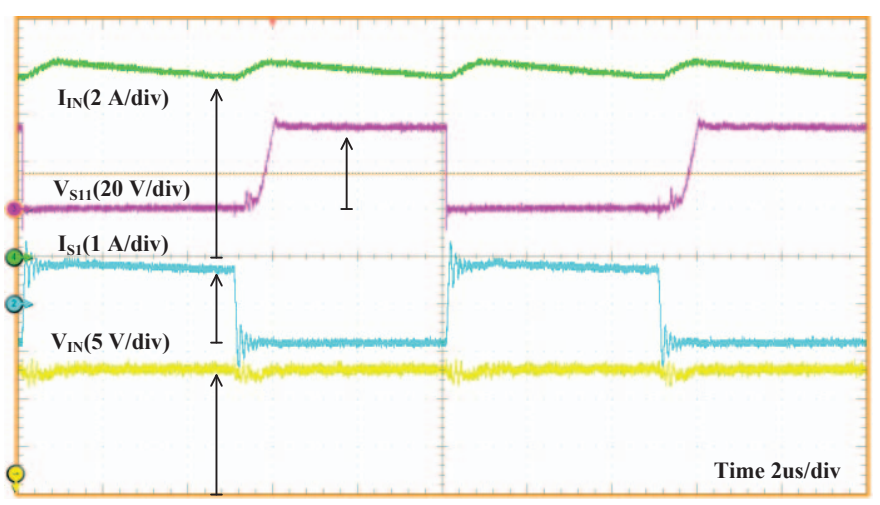

Fig. 10. Converter input voltage $\left(\mathrm{V}_{\mathrm{IN}}\right)$ and current $\left(\mathrm{I}_{\mathrm{IN}}\right)$ and voltage and current across 4Q switch $\mathrm{S} 1$. 


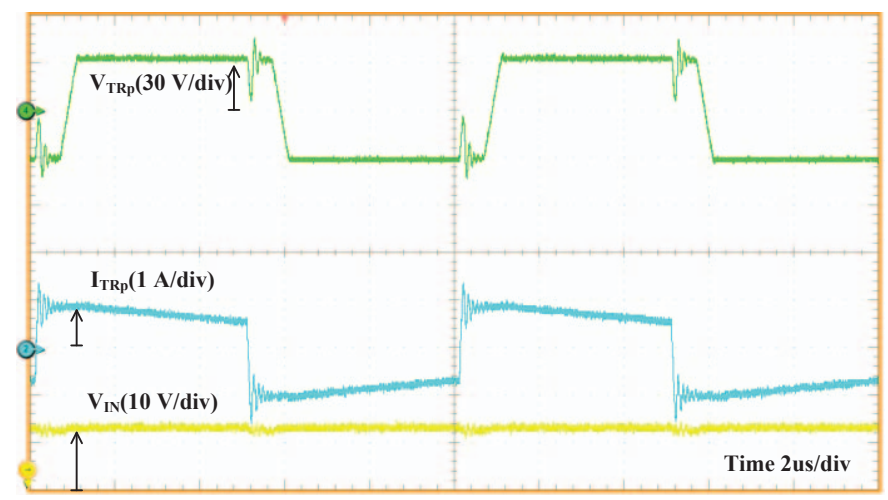

Fig. 11. Transformer primary voltage $\left(\mathrm{V}_{\mathrm{TRp}}\right)$ and current $\left(\mathrm{I}_{\mathrm{TRp}}\right)$ and converter input voltage $\left(\mathrm{V}_{\mathrm{IN}}\right)$.

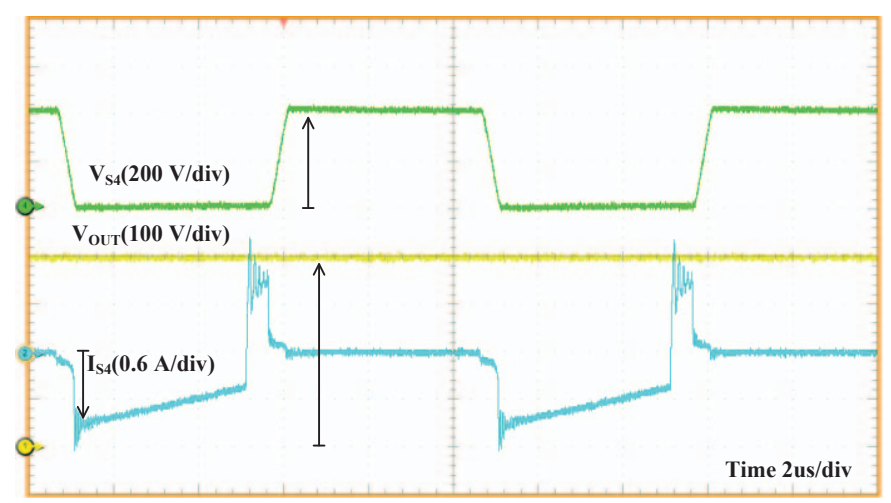

Fig. 12. Voltage $\left(\mathrm{V}_{\mathrm{S} 4}\right)$ and current $\left(\mathrm{I}_{\mathrm{S} 4}\right)$ across switch $\mathrm{S} 4$ and converter output voltage $\left(\mathrm{V}_{\text {OUT }}\right)$.

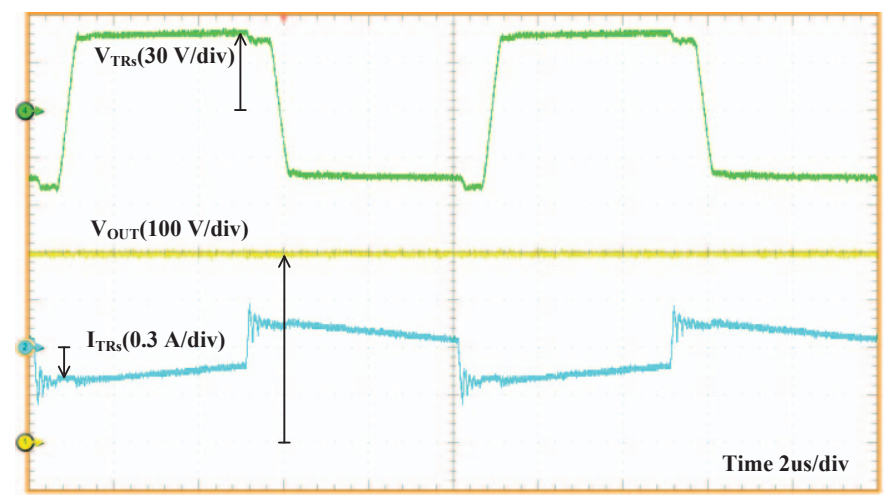

Fig. 13. Transformer secondary voltage $\left(\mathrm{V}_{\mathrm{TRs}}\right)$ and current $\left(\mathrm{I}_{\mathrm{TRs}}\right)$ and converter output voltage $\left(\mathrm{V}_{\text {OUT }}\right)$.

\section{CONCLUSIONS}

A novel bidirectional current-fed dual-inductor push-pull converter with galvanic isolation was introduced. It features full-soft-switching operation of all semiconductor components, while its DC voltage gain is higher than in traditional currentfed converters due to utilization of the circulating energy for the input voltage step-up. Moreover, it does not require any clamping circuits, since the novel control algorithm proposed features natural clamping of the switches at the current-fed side. The converter proposed can be used in BESSs achieving high switching frequency and, consequently, power density.

\section{ACKNOWLEDGMENT}

This work has been supported by the Estonian Research Council grant PUT744 and by the Estonian Centre of Excellence in Zero Energy and Resource Efficient Smart Buildings and Districts, ZEBE, grant 2014-2020.4.01.15-0016 funded by the European Regional Development Fund. Latvian partner research work has been supported by Latvian Council of Science (Grant 416/2012)

\section{REFERENCES}

[1] F. Blaabjerg, and D.M. Ionel, "Renewable Energy Devices and Systems - State-of-the-Art Technology, Research and Development, Challenges and Future Trends," Electric Power Components and Systems, vol.43, no.12, pp.1319-1328, 2015.

[2] C, Heymans, S, B. Walker, S. B. Young, M. Fowler, "Economic analysis of second use electric vehicle batteries for residential energy storage and load-levelling," Energy Policy, vol. 71, pp. 22-30, Aug. 2014.

[3] J. Weniger, T. Tjaden, V. Quaschning, "Sizing of Residential PV Battery Systems," Energy Procedia, vol. 46, pp. 78-87,2014.

[4] S. J. Chiang, K. T. Chang and C. Y. Yen, "Residential photovoltaic energy storage system," IEEE Trans. Ind. Electron., vol. 45, no. 3, pp. 385-394, Jun 1998.

[5] S. X. Chen, H. B. Gooi and M. Q. Wang, "Sizing of Energy Storage for Microgrids," IEEE Trans. Smart Grid, vol. 3, no. 1, pp. 142-151, 2012.

[6] Z. Wang, C. Gu, F. Li, P. Bale and H. Sun, "Active Demand Response Using Shared Energy Storage for Household Energy Management," IEEE Trans. Smart Grid, vol. 4, no. 4, pp. 1888-1897, Dec. 2013.

[7] B. Dunn, H. Kamath and J.Tarascon, "Electrical energy storage for the grid: a battery of choices," Science, vol. 334, pp. 928-35, 2011.

[8] A. I. Stan, M. Świerczyński, D. I. Stroe, R. Teodorescu and S. J. Andreasen, "Lithium ion battery chemistries from renewable energy storage to automotive and back-up power applications - An overview," Proc. OPTIM'2014, pp. 713-720, 2014.

[9] M. S. Whittingham, "History, Evolution, and Future Status of Energy Storage," Proc. IEEE, vol. 100, pp. 1518-1534, May 2012.

[10] V. Fernão Pires, E. Romero-Cadaval, D. Vinnikov, I. Roasto, J. F. Martins, "Power converter interfaces for electrochemical energy storage systems - A review," Energy Conversion and Management, vol. 86, pp. 453-475, October 2014.

[11] X. Kong, L. T. Choi and A. M. Khambadkone, "Analysis and control of isolated current-fed full bridge converter in fuel cell system," Proc. IECON'2004, vol. 3, pp. 2825-2830, 2004.

[12] N.M.L. Tan, T. Abe, H. Akagi, "Design and Performance of a Bidirectional Isolated DC-DC Converter for a Battery Energy Storage System," IEEE Trans. Power Electron., vol. 27, no. 3, pp. 1237-1248, March 2012.

[13] U. R. Prasana and A. K. Rathore, "Extended Range ZVS ActiveClamped Current-Fed Full-Bridge Isolated DC/DC Converter for Fuel Cell Applications: Analysis, Design, and Experimental Results," IEEE Trans. Ind. Electron., vol. 60, no. 7, pp. 2661-2672, July 2013.

[14] R. L. Andersen and I. Barbi, "A ZVS-PWM Three-Phase Current-Fed Push-Pull DC-DC Converter," IEEE Trans. Ind. Electron., vol. 60, no. 3, pp. 838-847, March 2013.

[15] R. Y. Chen et al., "Study and Implementation of a Current-Fed FullBridge Boost DC-DC Converter With Zero-Current Switching for HighVoltage Applications," IEEE Trans. Ind. Appl., vol. 44, no. 4, pp. 1218 1226, July-aug. 2008.

[16] H. Wang et al., "A ZCS Current-Fed Full-Bridge PWM Converter With Self-Adaptable Soft-Switching Snubber Energy," IEEE Trans. Power Electron., vol. 24, no. 8, pp. 1977-1991, Aug. 2009.

[17] D. Chakraborty, A. K. Rathore, E. Breaz and F. Gao, "Parasitics assisted soft-switching and naturally commutated current-fed bidirectional pushpull voltage doubler," Proc. 2015 IEEE Industry Applications Society Annual Meeting, Addison, TX, 2015, pp. 1-8. 
[18] W. C. P. De Aragao Filho and I. Barbi, "A comparison between two current-fed push-pull DC-DC converters-analysis, design and experimentation," Telecommunications Energy Conference, 1996. INTELEC '96., 18th International, Boston, MA, 1996, pp. 313-320.

[19] K. R. Sree and A. K. Rathore, "Hybrid Modulated Extended Secondary Universal Current-Fed ZVS Converter for Wide Voltage Range: Analysis, Design, and Experimental Results," in IEEE Transactions on Industrial Electronics, vol. 62, no. 7, pp. 4471-4480, July 2015.

[20] K. R. Sree and A. K. Rathore, "Impulse Commutated Zero-Current Switching Current-Fed Push-Pull Converter: Analysis, Design, and Experimental Results," in IEEE Transactions on Industrial Electronics, vol. 62, no. 1, pp. 363-370, Jan. 2015.

[21] A. K. Rathore and P. U R, "Analysis, Design, and Experimental Results of Novel Snubberless Bidirectional Naturally Clamped ZCS/ZVS Current-Fed Half-Bridge DC/DC Converter for Fuel Cell Vehicles," in IEEE Transactions on Industrial Electronics, vol. 60, no. 10, pp. 44824491, Oct. 2013

[22] D. R. Nayanasiri, G. H. B. Foo, D. M. Vilathgamuwa and D. L. Maskell, "A Switching Control Strategy for Single- and Dual-Inductor CurrentFed Push-Pull Converters," in IEEE Transactions on Power Electronics, vol. 30, no. 7, pp. 3761-3771, July 2015.

[23] P. Xuewei and A. K. Rathore, "Naturally Clamped Zero-Current Commutated Soft-Switching Current-Fed Push-Pull DC/DC Converter: Analysis, Design, and Experimental Results," IEEE Trans. Power Electron., vol. 30, no. 3, pp. 1318-1327, March 2015.

[24] U. R. Prasanna, A. K. Rathore and S. K. Mazumder, "Novel ZeroCurrent-Switching Current-Fed Half-Bridge Isolated DC/DC Converter for Fuel-Cell-Based Applications," IEEE Trans. Ind. Appl., vol. 49, no. 4, pp. 1658-1668, July-Aug. 2013.

[25] A. Chub, R. Kosenko and A. Blinov, " Zero-Voltage Switching Galvanically Isolated Current-Fed Full-Bridge DC-DC Converter," Proc. CPE-POWERENG'2016, 5 pp., to be published, 2016.

[26] D. R. Nayanasiri, et al. "A Switching Control Strategy for Single- and Dual-Inductor Current-Fed Push-Pull Converters," IEEE Trans. Power Electron., vol. 30, no. 7, pp. 3761-3771, July 2015.

[27] A. Blinov, D. Vinnikov, and V. Ivakhno, "Full soft-switching high stepup dc-dc converter for photovoltaic applications," Proc. EPE'14ECCE Europe, pp. 1 -7, Nov. 2014.

[28] R. Kosenko, O. Husev and A. Chub, "Full soft-switching high step-up current-fed DC-DC converters with reduced conduction losses," Proc. POWERENG'2015, pp.170-175, 11-13 May 2015.

[29] A. Chub et al., "Full soft-switching bidirectional current-fed DC-DC converter," Proc.RTUCON'2015, pp.1-6, 14-14 Oct. 2015

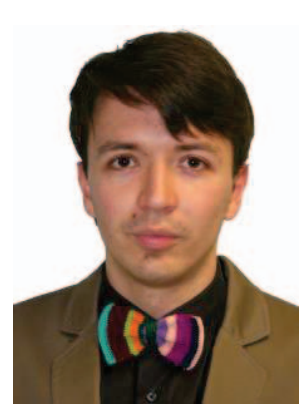

Roman Kosenko received Dipl.-Eng and M.Sc. in Electronics from the Department of Industrial Electronics, Chernihiv State University of Technology, Chernihiv, Ukraine, in 2011 and 2013, respectively. He is currently working toward the Ph.D. degree at the Department of Electrical Engineering of Tallinn University of Technology and at the Biomedical Radioelectronic Apparatus and Systems Department of Chernihiv National University of Technology. His fields of interest include research, design and simulation of switch mode converters for distributed power generation systems. He is author or co-author of 14 scientific papers and is the holder of 3 utility models in the field of power electronics.

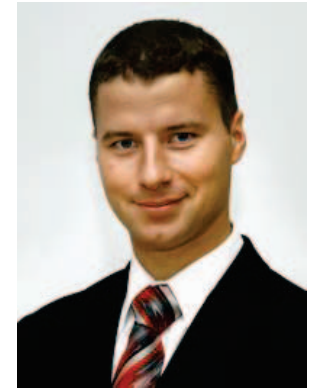

Janis Zakis received B. Sc., M. Sc. and Dr. Sc. Ing. in electrical engineering from Riga Technical University, Riga, Latvia, in 2002, 2004 and 2008, respectively. He is currently a Senior Researcher with the Institute of Industrial Electronics and Electrical Engineering, Riga Technical University. He has over 50 publications in journals and conference proceedings. His current research interests include design and simulation of novel multilevel converter topologies, applied design of power converters and energy storage systems.

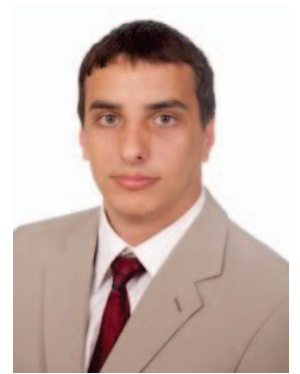

Andrei Blinov received the M.Sc and Ph.D. degrees in electrical drives and power electronics from Tallinn University of Technology, Estonia, in 2008 and 2012, respectively. From year 2012 he holds senior researcher position at the Department of Electrical Engineering of Tallinn University of Technology. Research interests of Andrei Blinov include research of switch-mode power converters, semiconductor heat dissipation and different cooling aspects.

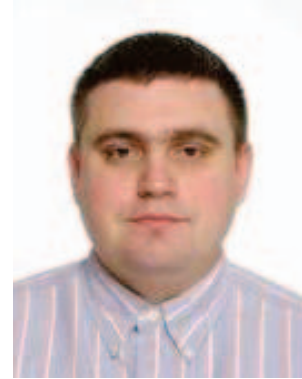

Andrii Chub received the B.Sc. degree in Electronics and M.Sc. degree in Electronic Systems from Chernihiv State Technological University, Ukraine, in 2008 and 2009 respectively. He is currently pursuing the Ph.D. degree in the Power Electronics Research Group, Tallinn University of Technology, where he is employed as a Junior Researcher. He has coauthored more than 40 papers, several patents and utility models, as well as and one book chapter on wind energy systems. His research interests include impedance source electric energy conversion technology, implementation of the new wide bandgap semiconductors in power converters, and control of the renewable energy conversion systems.

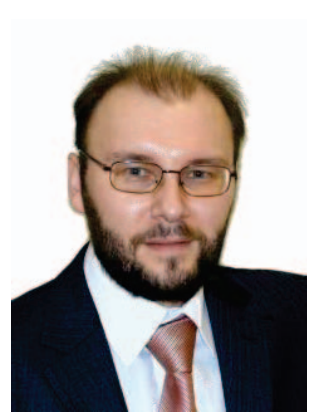

Oleksandr Velihorskyi received the B.Sc. and M.Sc. degrees in electronic systems from Chernihiv State University of Technology, Chernihiv, Ukraine, in 2001 and 2002, respectively. He received doctoral degree in semiconductor power converters from National Academy of Sciences, Institute of Electrodynamics, Kiev, Ukraine in 2007.

$\mathrm{He}$ is currently Head of Biomedical Radioelectronic Apparatus and Systems Department, Chernihiv National University of Technology. He has authored more than 20 published papers on power converters and is the holder of several Utility Models. His research interests include semiconductor power converters, photovoltaic, biomedical electronics. 